\title{
PENGAMALAN WANITA HAMIL DALAM MASYARAKAT MELAYU DARI PERSPEKTIF ISLAM
}

\section{Practices of Pregnant Women in Malay Communities from An Islamic Perspective}

\author{
Raihan Mohd Isa* \\ Saadan Man** \\ Noor Naemah Abd. Rahman*** \\ Norhidayah Pauzi ${ }^{* * * *}$
}

\begin{abstract}
The rich and powerful Malays hold on to various tips and taboos inherited from previous generations covering all aspects of their lives. Among them are tips and taboos involving nutrition, beauty, safety and health aspects of pregnant women. This practice aims to preserve the health and safety of pregnant women from any disturbance related to the beliefs of the Malay community at that time. However, these tips and taboos need to be examined so that they do not contain elements that are contrary to Islamic
\end{abstract}

* Postgraduate Student, Department of Fiqh and Usul, Academy of Islamic Studies, University of Malaya, raihanisa76@gmail.com

** Senior Lecturer, Department of Fiqh and Usul, Academy of Islamic Studies, University of Malaya, saadan@um.edu.my

*** Associate Professor, Department of Fiqh and Usul, Academy of Islamic Studies, University of Malaya, naemah@um.edu.my

**** Senior Lecturer, Department of Fiqh and Usul, Academy of Islamic Studies, University of Malaya, da_my85@um.edu.my 
values. This article discusses practices related to the tips and taboos for pregnant women among the Malay community according to an Islamic law perspective. The study uses library research (documentation method) by collecting data through primary and secondary sources and analyzed from an Islamic law perspective. The findings show that some tips and taboos that are in line with the teachings of Islam can be practiced, while some contradict with the values of Islam. In this regard, the community must be careful in practicing the traditions and beliefs so that they will not fall into the superstition trap.

Keywords: tips, taboo, pregnant women, Malay community, Islam

\section{PENDAHULUAN}

Pembinaan asas budaya Melayu sudah boleh dikesan sejak zaman prasejarah, iaitu zaman sebelum terdapat catatan bertulis tentang perkembangan manusia peringkat itu. ${ }^{1}$ Orang-orang Melayu di rantau ini pada mulanya dipercayai berasal dari sebelah utara Indo China yang bergerak ke selatan kerana mencari bahan-bahan makanan. Mereka berpindah dari satu tempat ke satu tempat dengan mencari kawasan yang subur dengan pelbagai tumbuhtumbuhan dan dipercayai tinggal di gua-gua batu dengan mencipta sendiri peralatan yang ingin digunakan untuk keperluan hidup, seperti alat-alat yang diperbuat daripada batu, kayu dan logam. ${ }^{2}$ Tambahan pula, alatan yang dihasilkan oleh mereka tidak tertumpu kepada fungsi semata-mata bahkan penuh dengan keindahan dan kehalusan apabila ianya dilengkapi seni ukiran dan motif penghasilan yang menarik. Apabila masyarakat Melayu ketika itu mula tinggal secara menetap dan tidak lagi berpindah randah, mereka bergiat aktif dalam bidang cucuk tanam dan penternakan haiwan. Masyarakat Melayu dipercayai telah membina peraturan sosial atau adat untuk menjamin kehidupan yang lebih harmoni dan stabil. Adat merupakan sebahagian daripada budaya yang

\footnotetext{
Wan Abdul Kadir, Tradisi dan Perubahan Masyarakat dan Budaya Melayu (Kuala Lumpur: Pustaka Ilmu, 2002), 2.

2 Ibid.
} 
diamalkan bersama-sama oleh sesuatu kumpulan sosial. Ianya merupakan amalan atau cara melakukan sesuatu yang telah diwarisi secara turun-temurun dari satu generasi ke generasi berikutnya. ${ }^{3}$ Kebanyakan adat bermula dari keinginan manusia untuk melihat jangkaan dalam sesuatu situasi sosial. Sistem adat mempunyai banyak persamaan dengan sistem budaya, iaitu kelakuan yang dipelajari dan diamalkan berbeza-beza mengikut kaum. Sebagai contoh, adat perkahwinan disambut dengan berbeza bergantung kepada kaum masing-masing.

Sebahagian sistem adat dipercayai berkekalan kerana masyarakat cenderung untuk terus patuh dari melanggarnya kerana bimbangkan hukuman berat yang menanti sekiranya adat tersebut dilanggar. Walau bagaimanapun, kebanyakan pelanggaran adat dihukumkan dengan hukuman yang ringan termasuklah pelanggaran adat dalam bab perkahwinan dan kematian. Bagi sesetengah masyarakat yang tinggal di kawasan kampung, kebanyakan adat yang diwarisi dari generasi ke satu generasi masih tidak mengalami perubahan kerana mereka berusaha mempertahankan tradisi yang diwarisi sekian lama walaupun proses urbanisasi dan modenisasi amat pesat melanda negara ini. Namun demikian, unsur-unsur budaya bandaran turut meresap dan mempengaruhi kehidupan mereka berikutan pesatnya pembangunan pada peringkat luar bandar selepas negara mencapai kemerdekaan. Orang-orang Melayu yang tinggal di kampung yang berdekatan dengan bandar, sedikit demi sedikit mengalami perubahan dan meninggalkan gaya hidup tradisi. Walaupun begitu, penduduk kampung di pedalaman masih mengekalkan corak kehidupan yang penuh dengan tradisi meskipun terdapat bahagian-bahagian tertentu yang menerima pembaharuan. ${ }^{4}$ Berbeza pula dengan kehidupan masyarakat Melayu yang tinggal di bandar, perubahan adat mudah berlaku dan dipengaruhi dengan beberapa faktor antaranya ciptaan baru dan pertembungan dengan adat kaum lain.

3 Ensiklopedia Dunia (Kuala Lumpur: Dewan Bahasa dan Pustaka, 2005), 49.

4 Wan Abdul Kadir, Tradisi dan Perubahan Masyarakat dan Budaya Melayu, 147. 
Oleh itu, dapat difahami bahawa adat terbentuk melalui pengalaman dan kepercayaan mereka terhadap sesuatu perkara. Pengalaman dan kepercayaan ini diasaskan supaya mereka dapat menjalani hidup dengan aman dan sejahtera. Mereka berusaha membina kehidupan dengan menyesuaikan diri dengan alam dalam memenuhi keperluan-keperluan asas seperti makanan dan tempat tinggal. Proses penyesuaian tersebut menghasilkan banyak kemahiran antaranya dalam bidang pertukangan yang dapat dilihat melalui tinggalan artifak-artifak di muzium. Selain daripada itu, antara adat yang diperturunkan kepada generasi seterusnya adalah amalan-amalan bagi ibu hamil sepanjang tempoh kehamilan sehingga kelahiran anak. Menurut kepercayaan masyarakat Melayu, amalan ini bertujuan untuk memastikan ibu hamil terhindar dari gangguan jin dan syaitan, memudahkan proses kelahiran dan memulihkan kesihatan ibu dengan cepat. Justeru, artikel ini membincangkan proses kehamilan dan pemakanan semasa hamil, pengamalan ibu hamil dalam kalangan masyarakat Melayu serta analisis menurut perspektif hukum Islam.

\section{KEHAMILAN DAN PEMAKANAN SEMASA HAMIL}

Kehamilan bermula dengan konsepsi yakni persenyawaan telur oleh sperma dan berakhir dengan kelahiran, iaitu proses bersalin. Telur yang tersenyawa itu dikenali sebagai zigot. Kehamilan juga dikenali sebagai gestasi, berlangsung selama kira-kira sembilan bulan bagi kebanyakan wanita. Semasa dua bulan pertama kelahiran, zigot yang membesar dikenali sebagai embrio dan dikenali sebagai janin. Selepas dua bulan, janin akan bersaiz kirakira 2.5 sentimeter dan boleh menggerakkan kepala, mulut, lengan dan kakinya. Selepas tiga bulan pula, janin akan mempunyai sifat manusia yang dapat dicamkan. Pada saat ini, wanita akan merasa pergerakan pertama janin dalam perutnya ketika janin berusia lima bulan dan kebanyakan anggota tubuh janin sudah berfungsi. Semasa tempoh tiga bulan yang terakhir, aliran darah wanita membekalkan berbagai-bagai bahan yang menolong melindungi bayi daripada pelbagai penyakit setelah lahir nanti. Wanita hamil akan mengalami perubahan fizikal semasa tempoh kehamilan. Darah haid terhenti sehingga selepas wanita tersebut melahirkan 
anak. Semasa kehamilan tiga bulan yang pertama, wanita mungkin mengalami simptom mabuk hamil iaitu rasa mual dan muntah. ${ }^{5}$

Dalam aspek pemakanan pula, wanita hamil memerlukan makanan yang mempunyai nutrisi yang cukup untuk keperluannya dan bayi yang dikandung seperti pengambilan protein, asid folik dan vitamin B12. Wanita hamil yang berada pada trimester pertama memerlukan hanya 80 kalori sahaja yang bersamaan dengan sekeping roti. Namun begitu, kebanyakan wanita hamil yang tidak mempunyai alahan akan mengambil makanan sesuka hati tanpa mengira kalori yang diperlukan oleh tubuh badan. Ini kerana mereka menganggap bayi di dalam kandungan akan lapar sekiranya mereka tidak makan sedangkan nilai kalori yang diperlukan adalah rendah. ${ }^{6}$

Selain kalori, pengambilan protein, vitamin dan zat galian juga sangat penting untuk kesihatan wanita dan janin. Wanita hamil juga dinasihatkan untuk elak makan makanan pedas dan berminyak dan disarankan untuk menambah halia, lemon atau asam ke dalam minuman untuk menambahkan kesegaran semasa kehamilan. Dengan itu, diet mereka perlu diisi dengan makanan berkhasiat seperti buah-buahan, sayur-sayuran, susu rendah lemak, telur, keju dan bijirin. Wanita hamil tidak digalakkan mengambil makanan berkalori tinggi, berlemak, banyak gula dan garam. Makanan segera dan snek ringan yang tidak bernutrisi seharusnya dielakkan. Jika terasa ingin mengunyah, kekacang perisa asli, tidak bersalut coklat atau garam yang tinggi adalah pilihan yang sesuai. Begitu juga pengambilan makanan atau minuman yang boleh memudaratkan diri dan bayi seperti minuman beralkohol atau merokok seharusnya dihentikan kerana mungkin boleh mengganggu perkembangan bayi dalam kandungan. ${ }^{7}$

Justeru, wanita hamil yang mengambil pemakanan yang sihat dapat menambahkan nutrisi dan mengekalkan kesihatan tubuh

Ensiklopedia Dunia (Kuala Lumpur: Dewan Bahasa dan Pustaka, 2005), 464.

6 Ibid.

7 Siti Zarinah Sahib, "Jaga Pemakanan Semasa Hamil”, laman sesawang MyMetro, dikemaskini 21 Disember 2017, dicapai 30 Mei 2019, https:/www.hmetro.com.my/hati/2017/12/295517/jagapemakanan- ketika hamil, 
badan. Hal ini memerlukan wanita hamil berhati-hati dalam memilih makanan supaya dapat mengelakkan perkara-perkara yang buruk berlaku pada tubuh badan. Bagi memastikan kesihatan bayi terjamin, penjagaan dan pemakanan yang sempurna perlu dimulakan sejak dari dalam kandungan lagi. Berikut merupakan beberapa contoh makanan tambahan yang diperlukan oleh wanita hamil: ${ }^{8}$

\section{Asid Folik}

Asid folik ini adalah vitamin dalam kumpulan B. Asid folik membantu menguatkan rahim wanita (untuk yang belum mengandung) dan juga mengurangkan peratusan kelahiran bayi yang cacat. Sesetengah makanan seperti roti dan bijirin sarapan diperkuat dengan asid folik. Dalam masa 12 minggu pertama kehamilan, otak dan sistem saraf bayi terbentuk dan berkembang dengan pesat. Oleh sebab itu, adalah sangat penting untuk mengambil asid folik setiap hari pada masa itu.

\section{VCO Capsul - virgin coconut oil - kapsul minyak kelapa dara}

VCO Kapsul pula diambil untuk memudahkan proses kelahiran bayi dan juga khasiat di dalam minyak kelapa dara itu sendiri. Ini kerana minyak kelapa mempunyai kandungan yang luar biasa. Selain mematikan pelbagai mikroorganisma berbahaya kandungan MCFA (asid laurik, asid kaprilik, asid kaprat, asid oleik, asid miristat, asam palmitat) dalam VCO juga memberikan tenaga yang diperlukan semasa melahirkan bayi. Pengambilan VCO semasa hamil memberikan pengaruh yang sangat baik untuk bayi, bukan sahaja semasa di dalam kandungan bayi lebih sihat, bahkan bayi akan berada dalam keadaan bersih dan sihat ketika lahir. Selain itu, VCO membuat pengeluaran susu menjadi lebih banyak dan lebih berkualiti.

8 "Vitamin dan Suplemen Kesihatan Untuk Ibu Hamil" laman Portal Rasmi Myhealth dikemaskini 16 Disember 2013, dicapai 14 Jun 2019, http://www.myhealth.gov.my/vitamin-dan-suplemenkesihatan-untuk-ibu- hamil/. 


\section{Buah Delima dan Pati Buah Delima}

Buah delima mengandungi beberapa khasiat yang telah terbukti baik untuk jantung dan boleh membantu mengurangkan tekanan darah tinggi. Selain kaya dengan vitamin $\mathrm{C}$, buah delima sangat baik untuk sistem imun badan si ibu. Kajian telah menunjukkan bahawa pengambilan buah delima mempunyai kesan positif ke atas kesihatan tulang dan baik untuk bayi. Buah delima juga mempunyai khasiat anti-oksida yang banyak. Jadi, ianya sangat sesuai untuk wanita hamil yang mempunyai kulit kering, jerawat dan menggalakkan pertumbuhan semula sel yang sihat.

\section{Susu Segar}

Susu adalah sumber pemakanan penting terutamanya dalam memberikan khasiat kalsium dan pelbagai nutrien lain. Jika pengambilan kalsium tidak mencukupi semasa mengandung, badan janin akan menyerap kalsium dari tulang si ibu untuk memenuhi keperluan, oleh itu adalah penting untuk mendapatkan kalsium yang mencukupi untuk kesihatan si ibu dan bayi. Susu adalah sumber yang boleh dipercayai untuk mendapatkan protein; secawan susu rendah lemak menawarkan $8.22 \mathrm{~g}$ protein. Ini adalah bekalan tambahan protein digunakan untuk membina rahim, pembentukan semula payudara dan tisu bayi. Kekurangan protein boleh menyebabkan beberapa masalah kesihatan pada bayi termasuk berat bayi semasa lahir lebih rendah. Vitamin D yang dibekalkan oleh susu membantu dalam mencegah berat bayi rendah.

Penjagaan pemakanan ini perlu diteruskan ketika berpantang. Ini boleh dilakukan dengan mengambil sayur-sayuran, makanan kaya protein seperti ikan atau ayam dan memperbanyakkan minum air kosong bagi mengelak sembelit dan memastikan susu badan sentiasa ada. Walau bagaimanapun, ramai beranggapan makanan dalam pantang harus dicatu dan hanya makan ikan masin. Tetapi hakikatnya, penting bagi wanita mengambil makanan berkhasiat bukan sahaja untuk kesihatan dirinya bahkan untuk kesihatan bayi juga. 


\section{PENGAMALAN WANITA HAMIL DALAM MASYARAKAT MELAYU}

Menurut Kamus Dewan, petua didefinisikan sebagai nasihat, petunjuk, atau panduan yang berguna (biasanya oleh orang tuatua atau yang berpengalaman) tentang cara melaksanakan atau mencapai sesuatu dengan berkesan. ${ }^{9}$ Petua juga dijelaskan sebagai satu garis panduan secara tidak formal yang diperturunkan kepada anak cucu. ${ }^{10}$ Pantang larang pula bermaksud sesuatu yang dilarang daripada melakukannya menurut adat dan kepercayaan. ${ }^{11}$ Petua dan pantang larang yang melibatkan wanita hamil bertujuan untuk mengelakkan perkara buruk daripada berlaku. Setiap petua dan pantang larang mempunyai kebaikan yang tersendiri dan diwarisi menerusi lisan dari generasi nenek moyang terdahulu. Kemudian, amalan itu dipraktikkan untuk memelihara kesejahteraan hidup.

Variasi petua dan pantang larang yang wujud merangkumi aspek pemakanan dan kepercayaan. Segala nasihat ini berkaitan dengan adat dan kepercayaan selain unsur keadaan sekeliling juga mempengaruhi kewujudan nasihat, petunjuk, panduan yang kemudiannya dirumuskan sebagai petua Melayu. Lazimnya, pembentukan petua dan pantang larang masyarakat Melayu terdahulu lahir daripada pengalaman dan kepercayaan masyarakat Melayu terhadap kuasa ghaib dan diamalkan kerana dipercayai memberi kesan yang baik kepada kehidupan mereka. Untuk penjelasan lanjut, disenaraikan petua dan pantang larang bagi wanita hamil seperti berikut:

9 Kamus Dewan Online, dicapai 10 Oktober 2018, http://prpm.dbp. gov.my/caril ?keyword=petua

10 Yusmilayati Yunos et. al, "Kepandaian Orang Melayu dalam Mentafsir Ruang Perubatan Tradisional," Malaysia Journal of Society and Space 12 (11) (2016): 79-91.

11 Kamus Dewan Online, dicapai 10 Oktober 2018, http://prpm.dbp. gov.my/Caril ?keyword=pantang+larang 
Jadual 1.1: Petua dan pantang larang bagi wanita hamil ${ }^{12}$

\begin{tabular}{|c|c|}
\hline $\begin{array}{c}\text { Jenis Petua dan Pantang } \\
\text { Larang }\end{array}$ & $\begin{array}{l}\text { Sebab Dilarang/ } \\
\text { Dilakukan }\end{array}$ \\
\hline $\begin{array}{l}\text { Dilarang mengambil makanan } \\
\text { yang bersifat panas, sejuk, } \\
\text { berangin, gatal, berbisa dan } \\
\text { tajam }\end{array}$ & $\begin{array}{l}\text { Mengelakkan } \\
\text { kesakitan }\end{array}$ \\
\hline $\begin{array}{l}\text { Dilarang untuk makan sambil } \\
\text { menjuntaikan kaki di anak } \\
\text { tangga rumah. }\end{array}$ & $\begin{array}{l}\text { Mengelakkan pintu rahim } \\
\text { wanita tersekat semasa } \\
\text { proses kelahiran }\end{array}$ \\
\hline $\begin{array}{l}\text { Dilarang merasa masakan } \\
\text { melalui senduk }\end{array}$ & $\begin{array}{l}\text { Ditakuti anak bermulut } \\
\text { celupar dan bercakap kasar }\end{array}$ \\
\hline Mengidam & $\begin{array}{l}\text { Anak mempunyai lelehan } \\
\text { air liur sehingga dewasa }\end{array}$ \\
\hline Kenan dan badi & $\begin{array}{l}\text { Bayi yang lahir akan } \\
\text { memperoleh kecacatan atau } \\
\text { mempunyai masalah yang } \\
\text { berkaitan dengan haiwan } \\
\text { yang dibunuh }\end{array}$ \\
\hline Tidak memotong ketam & Ditakuti anak menjadi cacat \\
\hline $\begin{array}{l}\text { Tidak terpukul atau } \\
\text { terserempak ular }\end{array}$ & $\begin{array}{l}\begin{array}{l}\text { Ditakuti tali pusat anak } \\
\text { terbelit }\end{array} \\
\end{array}$ \\
\hline $\begin{array}{l}\text { Tidak menjerat burung dan } \\
\text { mengikat tali }\end{array}$ & $\begin{array}{l}\text { Ditakuti terbelit tali pusat } \\
\text { bayi yang bakal dilahirkan }\end{array}$ \\
\hline $\begin{array}{l}\text { Tidak mengail, menyiang ikan, } \\
\text { menyembelih, mengasari atau } \\
\text { membunuh binatang }\end{array}$ & $\begin{array}{l}\text { Ditakuti anak menjadi } \\
\text { sumbing atau cacat anggota } \\
\text { lainnya atau kelihatan seperti } \\
\text { haiwan yang dianiaya }\end{array}$ \\
\hline $\begin{array}{l}\text { Tidak makan sambal } \\
\text { berlebihan }\end{array}$ & Ditakuti kepala janin botak \\
\hline
\end{tabular}

12 Anisah Barakbah, Ensiklopedia Perbidananan Melayu (Kuala Lumpur: Utusan Publications, 2007), 72-81. 


\begin{tabular}{|l|l|}
\hline $\begin{array}{l}\text { Tidak mengetuk paku di } \\
\text { dinding, duduk di atas akar } \\
\text { kayu atau makan makanan } \\
\text { berakar seperti pegaga }\end{array}$ & $\begin{array}{l}\text { Ditakuti terlekat uri pada } \\
\text { rahim }\end{array}$ \\
\hline Tidak makan durian berlebihan & $\begin{array}{l}\text { Ditakuti kepala anak akan } \\
\text { berbisul setiap kali musim } \\
\text { durian. }\end{array}$ \\
\hline $\begin{array}{l}\text { Tidak boleh menyusup bawah } \\
\text { penyidai }\end{array}$ & Ditakuti anak cacat \\
\hline Tidak melihat gerhana & $\begin{array}{l}\text { Ditakuti anak bermata } \\
\text { juling atau ada tanda hitam }\end{array}$ \\
\hline $\begin{array}{l}\text { Tidak tidur tengah hari atau } \\
\text { menanam pokok pisang }\end{array}$ & $\begin{array}{l}\text { Ditakuti anak lahir } \\
\text { berkepala besar }\end{array}$ \\
\hline $\begin{array}{l}\text { Tidak digalakkan meminum } \\
\text { kopi }\end{array}$ & $\begin{array}{l}\text { Dibimbangi bayi berkulit } \\
\text { gelap }\end{array}$ \\
\hline $\begin{array}{l}\text { Tidak melangkah kucing yang } \\
\text { sedang tidur }\end{array}$ & $\begin{array}{l}\text { Dikhuatiri mata anak akan } \\
\text { tertutup seperti kucing } \\
\text { sedang tidur }\end{array}$ \\
\hline $\begin{array}{l}\text { Tidak tidur di tepi tingkap } \\
\text { yang terbuka atau baring } \\
\text { menghadap langit ketika bulan } \\
\text { sedang mengambang }\end{array}$ & $\begin{array}{l}\text { Ditakuti akan } \\
\text { gangguan jin atau makhluk } \\
\text { halus }\end{array}$ \\
\hline Adat melenggang perut & $\begin{array}{l}\text { Untuk mengetahui jantina } \\
\text { bayi yang bakal dilahirkan }\end{array}$ \\
\hline
\end{tabular}

Berdasarkan kepada Jadual 1.1 di atas, terdapat banyak petua dan pantang larang masyarakat Melayu dahulu yang perlu dititikberatkan oleh wanita hamil. Wanita hamil dilarang mengambil makanan yang bersifat panas, sejuk, berangin dan gatal untuk mengelakkan daripada kesakitan. Makanan yang berbisa dan tajam seperti buah nenas muda, air ragi, tapai, air kelapa muda, air tebu dan buah nangka dilarang keras kerana ditakuti wanita hamil mengalami pendarahan dan keguguran. Selain itu, mereka juga dilarang mengambil makanan yang bersifat panas seperti ramuan air akar kayu, maajun dan ubat-ubatan yang panas dan digalakkan 
mengambil makanan yang masam dan sejuk seperti buah mangga muda dan kedondong. Hal ini kerana wanita hamil dikategorikan berada dalam keadaan panas. ${ }^{13}$

Wanita hamil juga dilarang untuk makan sambil menjuntaikan kaki di anak tangga rumah. Hal ini kerana ianya akan menyebabkan pintu rahim wanita tersekat semasa proses kelahiran. Hal ini bertepatan dengan prinsip orang Melayu "jika hendak masuk, masuk terus dan jika hendak keluar, keluar terus". Ini adalah untuk mengelakkan si wanita daripada menanggung sakit yang terlalu lama. Wanita hamil dilarang merasa masakan melalui senduk. Sebaliknya kuah tersebut perlu dicedok ke dalam piring terlebih dahulu. Masyarakat Melayu percaya sekiranya pantang ini dilanggar, anak yang bakal lahir akan bermulut celupar dan bercakap kasar. ${ }^{14}$

Wanita hamil juga perlu menjaga kelakuan supaya dapat terhindar dari kuasa-kuasa jahat. Larangan ini mempunyai kaitan dengan kepercayaan masyarakat Melayu kepada unsur-unsur magis ${ }^{15}$ (Shariffah Suraya, 2014). Antara petua dan pantang larang lain yang diamalkan adalah wanita hamil mudah mengidam akibat daripada pembawakan bayi. Dikatakan bahawa makanan yang ingin dimakan merupakan hajat bayi. Sekiranya hajat ini tidak dipenuhi, dipercayai wanita tersebut akan kempunan. Hal ini menyebabkan bayi yang lahir itu akan mempunyai lelehan air liur sehingga dewasa.

Seterusnya, kepercayaan terhadap kenan dan badi. Kenan dimaksudkan sebagai keganjilan tertentu pada gerak geri atau kelakuan. ${ }^{16}$ Manakala badi merupakan kesan buruk yang dialami seseorang antaranya kerana mendekati mayat, bangkai atau

\footnotetext{
Ibid.

Ibid.

15 Shariffah Suraya Syed Jamaludin, "Petua dan Pantang Larang Berkaitan Kesihatan Wanita" dalam Amalan Kearifan Tempatan dalam Masyarakat Melayu/Nusantara, ed. Ahmad Moghni Salbani et al. (Pulau Pinang: Universiti Sains Malaysia, Pulau Pinang, 2014), 88.

16 Mohd Anuar Ramli dan Syamsul Azizul Marinsah, "Kepercayaan Kenan dalam Masyarakat Melayu: Kajian dari Perspektif Hukum Islam," Jurnal Manusia dan Masyarakat 25 (2014), 34.
} 
sesuatu yang dianggap keramat. Wanita hamil atau pasangan juga dilarang untuk membunuh atau menyeksa binatang kerana ditakuti bayi yang lahir akan memperoleh kecacatan atau mempunyai masalah yang berkaitan dengan haiwan yang dibunuh. Terdapat cerita mengatakan bahawa seorang bayi terkena kenan kera kerana berjalan mengangkang seperti kera. ${ }^{17}$

Selain itu, terkejut apabila terserempak atau melihat sesuatu. Salah satu daripada perkara yang tidak boleh dipandang ringan oleh wanita hamil ialah memastikan mereka tidak terkejut apabila terserempak atau melihat sesuatu, misalnya binatang atau keadaan fizikal seseorang. Jika wanita hamil terkejut, jangan memaki hamun atau menghina tetapi perlu bersabar dan sebut 'kus semangat awang dayang.' Itu petua yang diberikan orang dahulu yang mungkin merujuk ungkapan pada bayi lelaki atau perempuan. Ianya seolah-olah melindungi kandungan daripada terkejut dan menerima musibah. ${ }^{18}$

Wanita hamil juga biasanya digalakkan untuk menjaga emosi dan jangan menyimpan niat tidak elok atau berprasangka buruk sepanjang kehamilan, jangan derhaka kepada suaminya kerana akan berdepan kesukaran ketika mahu melahirkan, minum air kelapa pada bulan-bulan terakhir kehamilan supaya bayi berkeadaan bersih ketika dilahirkan, melihat benda-benda yang elok dan cantik supaya bayi juga berkeadaan elok dan cantik dari segi rupa dan peradaban, serta banyakkan berjalan dan melakukan senaman ringan, dan elakkan bermalas-malasan sahaja. ${ }^{19}$

Wanita hamil juga dipesan oleh generasi terdahulu supaya tidak memotong ketam ditakuti anak menjadi cacat, tidak terpukul atau terserempak ular ditakuti tali pusat anak terbelit, tidak menjerat

17 Shariffah Suraya Syed Jamaludin, "Petua dan Pantang Larang Berkaitan Kesihatan Wanita" dalam Amalan Kearifan Tempatan dalam Masyarakat Melayu/Nusantara, ed. Ahmad Moghni Salbani et al. (Pulau Pinang: Universiti Sains Malaysia, Pulau Pinang, 2014), 89.

18 "Pantang Larang Masyarakat Melayu Semasa Hamil" laman sesawang Baby Center, dicapai 15 Mei 2019, https://www.babycenter.com.my/ a25019657/pantang-larang-masyarakat-melayu-semasa-hamil.

Ibid. 
burung dan mengikat tali, takut susah ketika anak hendak dilahirkan kerana dikhuatiri terbelit tali pusat, tidak mengail, menyiang ikan, menyembelih, mengasari atau membunuh binatang, takut anak menjadi sumbing atau cacat anggota lainnya atau kelihatan seperti haiwan yang dianiaya, tidak makan sambal berlebihan, takut kepala janin botak, tidak mengetuk paku di dinding, duduk di atas akar kayu atau makan makanan berakar seperti pegaga ditakuti terlekat uri pada rahim, tidak makan durian berlebihan ditakuti kepala anak akan berbisul setiap kali musim durian.

Selain itu, wanita hamil juga tidak boleh menyusup di bawah penyidai ditakuti anak cacat, tidak melihat gerhana ditakuti anak bermata juling atau ada tanda hitam, tidak tidur tengah hari atau menanam pokok pisang ditakuti anak lahir berkepala besar, tidak diikat mati benang atau tali, menjahit atau pun menganyam ditakuti anak terbelit tali pusat, tidak duduk di muka pintu atau tangga ditakuti susah melahirkan termasuk kemungkinan berlaku tumpah darah yang boleh mendatangkan maut. Bahkan wanita hamil juga tidak digalakkan meminum kopi dibimbangi bayi berkulit gelap, tidak melangkah kucing yang sedang tidur dikhuatiri mata anak akan tertutup seperti kucing sedang tidur, tidak tidur di tepi tingkap yang terbuka atau baring menghadap langit ketika bulan sedang mengambang kerana ditakuti akan terkena gangguan jin atau makhluk halus. Sekiranya wanita terkena gangguan ini, mereka akan mudah mendapat kemurungan dan seterusnya menjadi gila merian. ${ }^{20}$

Selain daripada beberapa pantang larang yang dijelaskan di atas, wujud adat melenggang perut yang biasa dilakukan oleh bidan kampung untuk mengetahui jantina bayi yang bakal dilahirkan. Kebiasannya adat ini dilakukan semasa kandungan mencapai usia tujuh bulan dan dilakukan pada kandungan sulung. Buah kelapa merupakan antara alat utama yang perlu ada ketika upacara berlangsung. Bidan akan meletakkan buah kelapa di atas perut wanita dan membiarkannya jatuh sendiri. Sekiranya buah tersebut jatuh di kiri ibu, maka mereka meramalkan akan mendapat anak lelaki manakala jika jatuh ke sebelah kanan akan mendapat anak perempuan. Di sesetengah tempat, buah kelapa digolekkan dari perut menuju ke kaki wanita dan dibiarkan kelapa itu jatuh

20 Ibid. 
sendiri. Sekiranya mata kelapa berada di atas, maka bayi tersebut adalah lelaki manakala sekiranya mata kelapa berada di bawah, bayi yang bakal dilahirkan adalah perempuan. Buah kelapa tadi akan di belah dua dan airnya diberi kepada ibu. Baki daripada air tersebut akan dicurahkan pada kaki ibu. Walau bagaimanapun, sesetengah tempat meramalkan terlebih dahulu jantina yang bakal lahir sebelum buah kelapa dibelah. Seterusnya, bidan tersebut akan memerhati kaki si wanita setelah beliau bangun dari posisi duduk. Sekiranya langkah dimulakan dengan kaki kanan, maka bayi tersebut adalah lelaki manakala sekiranya kaki kiri bayi tersebut adalah perempuan. ${ }^{21}$

Berdasarkan kepada beberapa petua dan pantang larang yang dinyatakan di atas pelbagai aspek perlu diambil berat apabila seseorang wanita itu didapati hamil. Sehubungan itu, pantang larang bagi wanita hamil tidak terhad kepada amalan pemakanan sahaja bahkan larangannya meliputi segala aktiviti harian wanita hamil. Walau bagaimanapun, terdapat juga larangan kepada bapa iaitu pasangan kepada wanita hamil berkenaan.

Bapa juga ada pantang larang yang perlu dipatuhi walaupun tidak sebanyak larangan kepada wanita yang hamil. Ia dapat diringkaskan seperti berikut:

Jadual 1.2 Petua dan pantang larang bagi suami

\begin{tabular}{|l|l|}
\hline \multicolumn{1}{|c|}{$\begin{array}{c}\text { Jenis Petua dan Pantang } \\
\text { Larang }\end{array}$} & \multicolumn{1}{|c|}{ Sebab Dilarang } \\
\hline $\begin{array}{l}\text { Tidak boleh terus masuk ke } \\
\text { dalam rumah sekiranya pulang } \\
\text { pada waktu malam }\end{array}$ & $\begin{array}{l}\text { Untuk mengelirukan } \\
\text { hantu yang mengikutinya }\end{array}$ \\
\hline $\begin{array}{l}\text { Tidak boleh melakukan } \\
\text { pekerjaan yang "keras" seperti } \\
\text { menyembelih ayam, membunuh } \\
\text { binatang terutamanya ular, } \\
\text { monyet dan anjing. }\end{array}$ & $\begin{array}{l}\text { Boleh mengakibatkan } \\
\text { badi binatang tersebut } \\
\text { terkena kepada anaknya }\end{array}$ \\
\hline
\end{tabular}

21 Anisah Barakbah, Ensiklopedia Perbidananan Melayu, 76-81. 
Berdasarkan kepada Jadual 1.2 di atas, seorang suami apabila pulang ke rumah pada waktu malam tidak boleh terus masuk ke dalam rumah, tetapi perlu berhenti sebentar di luar rumah. Tujuannya adalah untuk mengelirukan hantu yang mengikutinya. Selain itu, bapa kepada bayi dalam kandungan tidak boleh melakukan pekerjaan yang "keras" seperti menyembelih ayam, membunuh binatang terutamanya ular, monyet dan anjing. Keadaan ini boleh mengakibatkan badi binatang tersebut terkena kepada anaknya dan dikhuatiri anak yang bakal lahir bibirnya terbelah, kenan atau mengalami kecacatan. ${ }^{22}$

Dari segi pemikiran rasional, tujuan larangan ke atas bapa daripada terus memasuki rumah adalah untuk meredakan bapa yang mungkin berkeadaan panas dan untuk mengembalikan semula keadaannya seperti bersifat tenang dan sabar apatah lagi apabila berhadapan dengan isteri yang sedang hamil ataupun beranak kecil. Pantang larang kepada bapa yang tidak dibenarkan melakukan perkara yang "keras" juga mendidik masyarakat supaya tidak melakukan penderaan terhadap binatang. Ini kerana perbuatan ini menggambarkan sikap manusia yang kejam dan zalim. ${ }^{23}$

\section{PENGAMALAN WANITA HAMIL MENURUT PERSPEKTIF ISLAM}

Sebelum kedatangan Islam, petua dan pantang larang masyarakat Melayu banyak dipengaruhi elemen-elemen daripada agama Hindu Buddha. Namun elemen-elemen ini dihapuskan setelah kedatangan Islam. Pengaruh agama Hindu Buddha tidak begitu kuat kerana agama ini tidak tersebar kepada golongan bawahan dan banyak dianuti oleh golongan atasan untuk menjaga kepentingan dan kedudukan masing-masing memandangkan agama Hindhu Buddha mengamalkan sistem kasta. ${ }^{24}$

22 Ani Haji Omar, "Pantang Larang dalam Kalangan Orang Melayu: Analisis Dari Perspektif Teori Spb4k," Melayu: Jurnal Antarabangsa Dunia Melayu 7, no. 1 (2014), 82.

23 Ibid.

24 Wan Abdul Kadir, Tradisi dan Perubahan Masyarakat dan Budaya Melayu, 5. 
Justeru, kedatangan Islam ke Tanah Melayu disambut baik oleh masyarakat Melayu kerana ajaran Islam yang meraikan kesamarataan dalam kalangan penganutnya dan berlaku proses difusi budaya apabila masyarakat Melayu menerima dan memandang tinggi terhadap nilai-nilai Islam. Hal ini menunjukkan bahawa agama Islam berjaya mengubah world view masyarakat Melayu apabila adat dan budaya mereka turut berubah atau diolah. ${ }^{25}$

Antara faktor yang dapat mengubah world view masyarakat Melayu adalah melalui kaedah penyebaran agama Islam di Tanah Melayu. Agama Islam telah disebarkan melalui pelbagai cara antaranya melalui pedagang-pedagang yang datang singgah berdagang di Tanah Melayu pada ketika itu. Selain itu, Islam juga menjadi kuat apabila istana dijadikan tempat utama dalam penyebaran ilmu. Pembesar istana melantik alim ulama untuk menjadi penasihat mereka dan sebarang aktiviti pengajaran ilmu amat digalakkan. Oleh itu, agama Islam yang meraikan semua pihak diterima dengan baik dan mampu untuk menyaingi sebaran agama lain pada ketika itu seterusnya menghapuskan sesetengah petua dan pantang larang yang dipengaruhi agama Hindu Buddha. ${ }^{26}$

Tidak dinafikan banyak petua dan pantang larang yang diamalkan oleh wanita hamil dan pasangan mempunyai kebaikannya yang tersendiri namun ianya perlu diperhalusi dengan lebih teliti supaya menepati kehendak dan ajaran Islam. Jadual 1.3 merupakan ringkasan analisis pengamalan petua dan pantang larang wanita hamil dari perspektif hukum Islam.

Jadual 1.3 Amalan Petua dan Pantang Larang Wanita Hamil

\begin{tabular}{|l|l|}
\hline Kategori & \multicolumn{1}{|c|}{ Huraian } \\
\hline & $\begin{array}{c}|c| \\
\text { Sekiranya memberikan manfaat dan } \\
\text { kebaikan kepada wanita hamil dan dapat } \\
\text { mengelakkan kejadian buruk berlaku, terutamanya }\end{array}$ \\
Diterima & $\begin{array}{l}\text { Petua dan pantang larang yang boleh } \\
\text { diterima dengan pemikiran rasional dan berkaitan } \\
\text { dengan adat resam yang tidak menyalahi akidah } \\
\text { Islam }\end{array}$ \\
\hline
\end{tabular}

25 Ibid.

26 Ibid. 


\begin{tabular}{|c|l|}
\hline Ditolak & $\begin{array}{l}\bullet \quad \text { Bertentangan dengan nas syarak } \\
\text { - Berkaitan dengan kepercayaan kepada perkara } \\
\text { tahyul, khurafat dan syirik. }\end{array}$ \\
\hline \multirow{2}{*}{ Diolah } & $\begin{array}{l}\bullet \text { Elemen fasid dalam petua dan pantang larang } \\
\text { tersebut dibuang atau digantikan dengan elemen } \\
\text { yang mempunyai nilai-nilai Islam }\end{array}$ \\
\hline
\end{tabular}

Jadual $1.3 \mathrm{di}$ atas merupakan ringkasan analisis terhadap beberapa bentuk amalan petua dan pantang larang wanita hamil daripada perspektif hukum Islam. Dalam adat orang Melayu memang terdapat petua dan pantang larang dikenakan kepada wanita hamil mahupun pasangannya. Ada petua dan pantang larang yang boleh dijadikan ikutan dan ada yang hanya sekadar adat semata-mata dan tidak perlu diikuti. ${ }^{27}$

Islam menggalakkan kepada wanita hamil dan pasangan supaya memperbanyakkan amalan-amalan baik seperti membaca al-Quran dan menunaikan sembahyang sunat dengan memohon kepada Allah SWT agar dikurniakan kesihatan yang baik kepada wanita dan anak yang bakal dilahirkan. ${ }^{28}$ Justeru, petua dan pantang larang yang terbukti memberi manfaat dan kebaikan kepada wanita hamil dan dapat mengelakkan kejadian buruk berlaku semasa tempoh kehamilan dan kelahiran boleh diikuti dan tidak dilarang oleh syarak. Ini adalah kerana petua dan pantang larang berkenaan mempunyai asasnya yang tersendiri misalnya melalui pengalaman yang terbukti berkesan dan tidak menyelewengkan akidah seorang Muslim.

Bahkan tidak menjadi kesalahan kepada generasi muda yang masih mengamalkan petua dan pantang larang yang diamalkan dalam kehidupan seharian sekiranya ia memberikan manfaat dan kebaikan kepada mereka khususnya kepada kesihatan dan keselamatan. Lazimnya, petua dan pantang larang yang diamalkan adalah untuk mengelakkan kejadian buruk daripada berlaku kepada wanita terutamanya sewaktu dalam tempoh kehamilan, kelahiran

27 Kazim Elias, Hukum Langar Pantang Larang, dikemaskini 3 disember 2017, dicapai 14 jun 2019, http://www.utusan.com.my/mega/agama/ hukum-langgar-pantang-larang-1.565406 
dan berpantang selama 40 hari ataupun lebih. ${ }^{29}$ Ia selaras dengan beberapa kaedah fiqhiyyah yang menyatakan bahawa amalan manusia dikira sebagai hujah yang wajib diamalkan ( استعمال الناس)

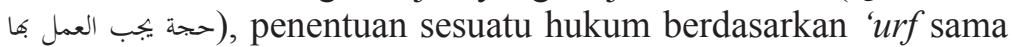
seperti penentuan hukum dengan nas (التعيين بالعرف كالتعيين بالنص) dan setiap hukum yang syarak datangkan secara mutlak, sedangkan tiada garis panduan terperinci pada syarak dan juga pada bahasa,

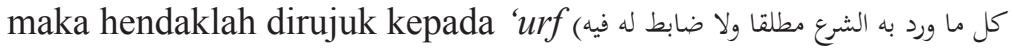
(ولا في اللغة يرجع فيه الى العرف

Manakala, petua dan pantang larang yang karut dan bertentangan dengan Islam seharusnya tidak diterima pakai lagi kerana mengandungi unsur-unsur animisme, Hindu Buddha yang jelas bercanggah dengan akidah Islam kerana mereka mempercayai wujudnya semangat dalam segala makhluk dan mempunyai kuasa-kuasa tertentu. Meskipun pengamalan masyarakat Melayu dahulu dicipta bertujuan untuk mendidik manusia dengan cara menakutkan mereka melalui kepercayaan kepada perkara-perkara tahyul dan khurafat, akan tetapi ianya telah melanggar nilai-nilai Islam yang sebenar. ${ }^{31}$

Berkenaan dengan larangan membunuh atau menyeksa binatang berbisa yang mengancam keselamatan dan membahayakan nyawa ataupun sebaliknya kerana ditakuti bayi yang lahir memperoleh kecacatan atau mempunyai masalah yang berkaitan dengan haiwan yang dibunuh, ${ }^{32}$ tindakan yang wajar dilakukan adalah menghalau dan mengusirnya terlebih dahulu atau elakkan binatang tersebut daripada dibunuh. Namun sekiranya haiwan ini berbisa dan mengancam keselamatan nyawa maka ketika ini haiwan tersebut boleh dibunuh. Misalnya ular yang masuk di luar rumah. Pertama,

29 "Pantang Larang Masyarakat Melayu Semasa Hamil" laman sesawang BabyCenter, dicapai 15 Mei 2019, https:/www.babycenter.com.my/ a25019657/pantang-larang-masyarakat-melayu-semasa-hamil.

30 Ahmad Muhammad Zarqa', Sharh al-Qawa 'id al-Fiqhiyyah, c. 2 (Dimashq: Dār al-Qalam, 1989), 219-222.

31 Kazim Elias, Hukum Langar Pantang Larang, dikemaskini 3 Disember 2017, dicapai 14 jun 2019, http://www.utusan.com.my/ mega/agama/hukum-langgar-pantang-larang-1.565406

32 "Pantang Larang Masyarakat Melayu Semasa Hamil" laman sesawang BabyCenter, dicapai 15 Mei 2019, https:/www.babycenter.com.my/ a25019657/pantang-larang-masyarakat-melayu-semasa-hamil. 
boleh dibunuh ular berbahaya yang berada di luar rumah kerana bisa dan bahayanya. ${ }^{33}$ Rasulullah SAW bersabda: ${ }^{34}$

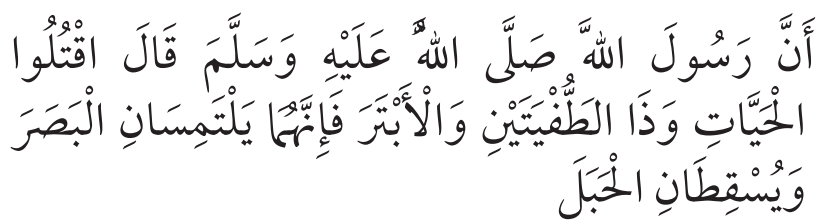

Terjemahan: Bunuhlah ular berbisa dan yang pendek, sesungguhnya kedua-duanya dapat menghilangkan penglihatan mata dan menggugurkan kandungan." (Muttafaq alaih).

Kedua, ular yang masuk ke dalam rumah. Nabi Muhammad SAW memerintahkan supaya menghalau ular terlebih dahulu dan jangan terus membunuhnya. Jika ular tersebut enggan keluar dari rumah, maka boleh membunuhnya. ${ }^{35}$ Nabi SAW bersabda: ${ }^{36}$

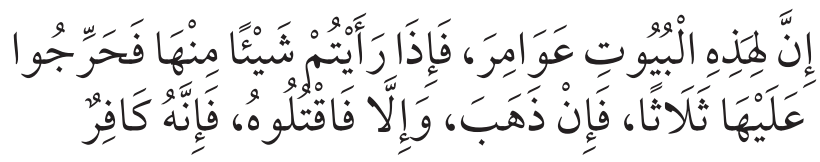

Terjemahan: Sesungguhnya rumah-rumah biasa ada ular yang masuk, maka jika engkau melihat salah satu ular tersebut, maka berilah peringatan terlebih dahulu sebanyak tiga kali. Dan jika ia pergi, maka itulah yang diharapkan. Dan jika ia enggan, maka bunuhlah, sesungguhnya ia adalah (syaitan) kafir." (Hadis riwayat Muslim).

Masyarakat Melayu juga sentiasa mengaitkannya dengan kenan. Menurut Kamus Dewan, perkataan kenan mempunyai dua

33 Kazim Elias, Hukum Langar Pantang Larang, dikemaskini 3 Disember 2017, dicapai 14 jun 2019, http://www.utusan.com.my/ mega/agama/hukum-langgar-pantang-larang-1.565406

34 Sharh Șahịh Muslim Imam Nawawi, kitab As-Salam, hadis no. 2233.

35 Kazim Elias, Hukum Langar Pantang Larang, dikemaskini 3 Disember 2017, dicapai 14 jun 2019, http://www.utusan.com.my/ mega/agama/hukum-langgar-pantang-larang-1.565406

36 Șahīh Muslim, Kitab As-Salam, hadis no. 4150. 
pengertian. Pertama, tanda atau cacat pada kulit, anggota, tubuh dan lain-lain semenjak lahir lagi. Kedua, keganjilan tertentu pada gerak geri, kelakuan dan lain-lain seperti tangisan yang menyerupai salakan anjing atau keganjilan gerak geri seperti menyerupai kera. ${ }^{37}$ Berdasarkan pengertian literal tersebut, kenan merupakan keadaan bayi yang tidak sempurna dan biasanya dikaitkan dengan karakter dan fizikal binatang tertentu seperti monyet, katak, ular dan sebagainya. Justeru, kenan adalah kecelakaan sama ada ianya penyakit atau kecacatan yang dialami oleh bayi yang baru dilahirkan akibat melanggar pantang larang yang dilakukan oleh si ibu atau bapa ketika bayi masih dalam kandungan. Ianya boleh terjadi kerana perbuatan membunuh, menyeksa binatang atau si pelaku melakukan sesuatu dalam keadaan lupa dirinya sedang mengandung. ${ }^{38}$ Oleh kerana itu, digalakkan kepada wanita hamil dan pasangan mengungkapkan istilah dan perbuatan yang baik kerana setiap perkataan dan perbuatan merupakan satu doa. Elakkan pintasan hati yang buruk dan sentiasa bersangka baik dengan apa yang berlaku dan mohon ampun kepada Allah SWT. ${ }^{39}$

Di antara adat resam yang masih lagi diamalkan oleh sebahagian masyarakat Melayu ialah adat melenggang perut. Istilah "lenggang perut" atau "kirim perut" atau "mandi tian" mengikut orang Melayu di sebelah Utara merupakan suatu adat yang dijalankan ke atas seorang perempuan mengandung yang telah genap tujuh bulan kandungannya. Tujuan diadakan adat melenggang perut ini ialah untuk membetulkan kedudukan anak di dalam kandungan perempuan yang hamil supaya anak tersebut

37 Kamus Dewan Online, dicapai 10 Jun 2019, http://prpm.dbp.gov.my/ Cari1 ?keyword=kenan\&d=158212\&\#LIHATSINI. Lihat juga Mohd Anuar Ramli dan Syamsul Azizul Marinsah, "Kepercayaan Kenan dalam Masyarakat Melayu: Kajian dari Perspektif Hukum Islam," 34.

38 Mohd Anuar Ramli dan Syamsul Azizul Marinsah, "Kepercayaan Kenan dalam Masyarakat Melayu: Kajian dari Perspektif Hukum Islam", 34.

39 Kazim Elias, Hukum Langgar Pantang Larang, dikemaskini 3 Disember 2017, dicapai 14 Jun 2019, http://www.utusan.com.my/ mega/agama/hukum-langgar-pantang-larang-1.565406 
mudah dilahirkan. Biasanya adat ini dilakukan pada tangga1 19 atau 21 atau 23 haribulan Islam. Hari yang paling baik ialah hari Rabu dan Khamis. ${ }^{40}$

Peralatan atau kelengkapan yang diperlukan untuk menjalankan adat ini ialah; i) 7 helai kain (sebaik-baiknya mempunyai warna yang berlainan dan salah satu daripadanya mestilah berwarna putih), ii) segantang beras yang dikenali sebagai "beras pemberkat", iii) wang pengeras (biasanya bagi masyarakat di Utara sebanyak RM 1.25), iv) 3 biji limau purut, v) sintuk, tepung tawar, bertih, beras kunyit, vi) minyak kelapa, vii) kelapa, viii) seekor ayam dara, ix) lilin dan beberapa urat benang mentah, $\mathrm{x}$ ) tepak sirih serta buyung yang dipenuhi air. ${ }^{41}$

Tok Bidan yang telah ditempah untuk menjalankan adat melenggang perut ini, terlebih dahulu akan mengandam perempuan hamil tersebut dengan jampi menteranya. Seterusnya kain tujuh warna tadi dibentangkan secara melintang sehelai di atas sehelai lagi. Kemudiannya perempuan yang hamil tadi dibaringkan di atas kain tersebut. Minyak kelapa atau urut disapukan pada perut perempuan tersebut. Lilin dipasangkan, tepung tawar dicalit ke muka perempuan hamil tersebut dan beras kunyit ditabur. Perbuatan ini disertai dengan jampi mentera serta doa. Setelah itu diambil pula kelapa yang telah dikupas kulitnya dan digulingkan ke atas perut perempuan sebanyak tujuh kali. Pada kali yang ketujuh dibiarkan kelapa itu jatuh sambil diperhatikan oleh Tok Bidan tentang bagaimana keadaan kelapa itu apabila ia berhenti bergolek. Jika mata kelapa itu berada di atas, perempuan tersebut akan beroleh anak lelaki, jika ke bawah perempuan tersebut akan memperolehi anak perempuan. ${ }^{42}$

Terdapat juga bidan yang tidak menggunakan kelapa untuk upacara tersebut sebaliknya menggunakan telur ayam. Upacara seterusnya ialah Tok Bidan akan memegang kedua-dua hujung

40 Machita Othman, "Adat Melenggang Perut di Kalangan Masyarakat Melayu,” Jurnal Warisan Indera Kayangan 5 (1993).

41 Ibid.

42 Ibid. 
kain lapisan yang teratas sekali dan kain tersebut dilengganglenggangkan di atas perut perempuan hamil sambil membaca doa. Dari perbuatan inilah terbitnya istilah lenggang perut. Kemudian kain itu ditarik keluar. Ia dilakukan sehingga habis ketujuh-tujuh helai kain tersebut. Kain yang di bawah sekali akan diberikan kepada Tok Bidan bersama-sama dengan beras, lilin, sirih pinang, ayam dara serta wang pengeras. Perempuan tersebut kemudiannya disuruh mandi bersintuk limau menggunakan air di dalam buyung tadi. Pada hari upacara itu dijalankan, biasanya diadakan kenduri nasi kunyit atau pulut kuning oleh kaum keluarga perempuan tersebut. ${ }^{43}$

Oleh kerana adat ini diwarisi sejak turun-temurun, maka terdapat sesetengah masyarakat hari ini masih lagi mengamalkannya. Adat melenggang perut dipercayai mengandungi budaya Hindu. Dalam kalangan masyarakat India yang beragama Hindu, adat melenggang perut dikenali dengan Valaikaappu, ia adalah adat yang dilakukan ketika kandungan sulung wanita hamil menjangkau usia tujuh hingga sembilan bulan. Wanita hamil tersebut akan dipakaikan sebentuk gelang tangan baru yang dikenali sebagai Suulkaappu, "Suul" maksudnya kandungan wanita dan "Kaappu" pula maksudnya perlindungan. Gelang ini dipakai bertujuan untuk melindungi bayi di dalam kandungan daripada kesukaran semasa bersalin. Adat Valaikaappu diadakan pada hari dan masa yang baik menurut kalendar India. ${ }^{44}$

Pada hari upacara dilakukan, hadiah kepada wanita hamil tersebut yang dikenali sebagai ciir diatur ke dalam dulang yang mempunyai bilangan ganjil. Hadiah ini termasuk barang kemas, sari, gelang tangan, serbuk kumkum, kunyit, buah-buahan, sirih pinang, sikat dan cermin serta pelbagai manisan. Hadiah di dalam dulang ini akan diletak di ruang tamu dan seterusnya upacara memandikan wanita hamil tersebut diadakan. Upacara ini juga

43 Ibid.

44 Mohamad Farid Mat Nazi "Amalan Khurafat dalam Kerukunan Rumahtangga di Kalangan Masyarakat Melayu Kajian di Daerah Peringat, Kelantan" (Kertas Projek Akhir di Universiti Pendidikan Sultan Idris, 2011), 22. 
dikenali sebagai mutugu niir (kulittal). Wanita hamil tersebut didudukkan di bilik mandi dan dimandikan dengan air seperti air susu, air kunyit, air kelapa muda, air mawar dan bunga-bungaan. Setelah mandi, wanita hamil tersebut akan dihias seperti pengantin dan seterusnya akan dikalungkan dengan kalungan bunga oleh suaminya. ${ }^{45}$

Wanita hamil tersebut dipakaikan dengan sari perkahwinan atau sari baru yang dibeli oleh bapanya dan didudukkan di ruang tamu. Seterusnya lampu minyak kuttu vilakku dihidupkan sebagai memohon restu Tuhan dan sebagai memulakan upacara. Berbagai makanan juga disediakan khas bagi wanita hamil tersebut seperti pelbagai jenis nasi, kuih muih, buah-buahan dan bunga-bungaan. Seterusnya wanita yang hamil itu akan memakan salah satu nasi yang disediakan. Nasi-nasi tersebut diletak di atas daun pisang berasingan dan seterusnya dibungkus dengan kain putih dan disimpul. Wanita hamil itu diminta membuka salah satu bungkusan yang diingini. Jika bungkusan yang dibuka adalah nasi manis, dipercayai anak yang bakal lahir adalah perempuan sebaliknya pula adalah lelaki. ${ }^{46}$

Berdasarkan keterangan ini, terdapat banyak persamaan yang sangat jelas di antara kedua-dua adat yang diamalkan ini. Meniru sesuatu perbuatan daripada agama lain adalah haram dalam Islam kerana ia dikhuatiri akan memesongkan akidah sebagai seorang Muslim. Adat ini tidak dinyatakan dalam nas al-Quran, Sunnah mahupun pendapat ulama yang muktabar. Ia adalah adat yang diwarisi dari nenek moyang. Adat ini diharamkan oleh Islam kerana ia berkait rapat dengan perkara tahyul dan khurafat kerana menggunakan jampi mentera yang jelas mengandungi unsurunsur mensyirikkan Allah SWT. Beramal dengan sesuatu yang tidak jelas disertai kepercayaan-kepercayaan karut jelas haram dalam Islam. Islam menganjurkan umatnya bergantung harap sepenuhnya kepada Allah SWT, hanya kepada Allah SWT sahaja

45 Ibid.

46 Ibid 
yang berkuasa menentukan baik dan buruk terhadap sesuatu perkara. ${ }^{47}$

Kini dengan peredaran zaman dan pengaruh sains dan teknologi, adat seperti ini tidak banyak diadakan lagi. Jika ia diadakan, pengubahsuaian dilakukan agar tidak bertentangan dengan agama Islam. Tambahan pula, wanita hamil kini sudah boleh mengetahui jantina bayi seawal usia bayi empat bulan lagi dengan menggunakan alat teknologi moden yang canggih tanpa perlu melakukan upacara sedemikian. Islam juga menggalakkan wanita hamil dan pasangan banyak memohon dan berdoa kepada Allah SWT supaya dimudahkan urusan bersalin serta diberikan kesihatan yang baik kepada wanita dan bayi yang bakal dilahirkan.

Selain itu, masyarakat Melayu juga mempercayai bahawa anak menantu yang bergaduh dengan ibu mentua akan mengalami kesulitan sewaktu ingin melahirkan anak. Namun begitu, tidak semestinya menantu yang mengalami kesulitan sewaktu melahirkan anak terjadi akibat daripada pergaduhan dengan mentua bahkan ia boleh berpunca daripada masalah yang berlaku dalam sistem peranakan si wanita atau faktor-faktor yang lain ${ }^{48}$ seperti kencing manis semasa hamil juga dikenali sebagai diabetes gestasi, tekanan darah tinggi atau hipertensi dan sebagainya yang boleh membahayakan kesihatan wanita dan bayi. ${ }^{49}$ Namun apa yang ingin disampaikan daripada pantang larang berkenaan adalah supaya kehidupan sesebuah keluarga tenteram dan aman terutamanya bagi menantu yang tinggal serumah dengan mentuanya. Suasana yang tidak harmoni dapat mempengaruhi emosi wanita hamil untuk menempuh saat melahirkan anak. ${ }^{50}$

Jika diteliti setiap pantang larang bagi wanita hamil mengandungi maksud tersirat untuk menjaga kemaslahatan

47 Ibid, lihat juga, Majlis Kenduri Adat Melenggang Perut http://www. jkkn.gov.my/ms/majlis-kenduri-adat-melenggang-perut, Jabatan Kesenian dan Kebudayaan Negara.

48 Ani Haji Omar, "Pantang Larang dalam Kalangan Orang Melayu: Analisis Dari Perspektif Teori Spb4k," 82.

49 Mustaffa Embong, "Diabetes Semasa Hamil", Tarikh kemaskini: 29/03/2019 http://www.bernama.com/bm/news.php?id=1710614

50 Ani Haji Omar, "Pantang Larang dalam Kalangan Orang Melayu: Analisis Dari Perspektif Teori Spb4k," 82. 
mereka. Larangan tidur waktu senja, jika mengikut pemikiran logik waktu senja ialah waktu yang hampir memasuki waktu Maghrib. Waktu tersebut merupakan masa untuk bersembahyang dan beribadat maka ia tidak sesuai untuk wanita hamil tidur pada masa berkenaan. Manakala pantang larang yang melarang wanita hamil makan makanan sejuk pula, rasionalnya dikhuatiri kesihatan wanita hamil akan terganggu seperti terkena batuk, demam dan selsema. Ini adalah kerana wanita hamil mudah terganggu kesihatannya jika tidak dijaga dari aspek pemakanan. Larangan wanita hamil tidak boleh duduk dibendul dan anak tangga pula, logiknya dibimbangi wanita terjatuh dan terlanggar oleh orang yang turun naik tangga. Hal ini selaras dengan kaedah fiqhiyyah yang menyatakan perkara yang dilarang pada adat sepertimana yang dilarang pada realitinya (المتنع عادة كالممتنع حقيقة).

Tidak dapat dinafikan bahawa bagi masyarakat terdahulu penjagaan terhadap wanita hamil adalah sangat penting. Masyarakat Melayu ketika ini banyak bergantung kepada perubatan tradisional bagi menjamin keselaman nyawa wanita dan anak yang bakal dilahirkan dengan harapan tiada sebarang kecacatan yang berlaku terhadap anak tersebut. Pelbagai petua dan pantang larang yang diberikan adalah untuk mengelakkan kejadian buruk berlaku semasa kehamilan, kelahiran serta berlanjutan dalam tempoh berpantang. Lazimnya, petua dan pantang larang ini diwarisi oleh nenek moyang secara turun-temurun dan diperturunkan secara lisan daripada ibu kepada anak, seterusnya kepada cucu dan kekal sebagai warisan.

Dalam kepesatan masyarakat menuju ke arah negara maju, masih wujud kekeliruan antara tuntutan agama dan adat yang menjadi pegangan kuat masyarakat Melayu. Bahkan, ada pepatah mengatakan "biar mati anak, jangan mati adat". Ini menggambarkan betapa masyarakat Melayu kuat berpegang pada adat dalam kehidupan. Walau bagaimanapun, masyarakat perlu memahami bahawa agama Islam tidak pernah menolak petua dan pantang larang selagi mana ia tidak bertentangan dengan syarak. Petua dan pantang larang yang tidak bercanggah dengan Islam harus dikekalkan dan boleh diwarisi kepada generasi akan datang. Ini adalah kerana kebanyakan petua dan pantang larang yang diamalkan oleh generasi terdahulu mempunyai hikmah tersendiri 
yang berkait rapat dengan akhlak dan bukan semua elemen mempunyai unsur yang menyesatkan.

Namun bagi sesetengah petua dan pantang larang, ianya mempunyai unsur-unsur animisme yang berkait dengan halhal ghaib seperti mempercayai semangat (roh) yang ada pada sesuatu benda seperti kayu atau batu, dan kuasa jahat yang wujud dalam dunia, atau kepercayaan dan keyakinan terhadap makhlukmakhluk halus dan kewujudan roh (spirit) dalam diri manusia, hasil daripada pelbagai pengalaman seperti mimpi, khayalan dan peristiwa kematian. Selain animisme, pengaruh agama dan budaya Hindu Buddha turut mewarnai kehidupan masyarakat Melayu pada zaman pemerintahan Raja-Raja Hindu dan Buddha. Kepercayaankepercayaan berkaitan agama tersebut mekar dalam kalangan masyarakat sehingga kedatangan Islam dari Timur Tengah dan Parsi yang menyebarluaskan pengaruhnya di Nusantara. ${ }^{51}$

Beramal dengan perkara-perkara khurafat, tahyul dan kebudayaan karut serta percaya ianya mempunyai kuasa selain daripada Allah SWT adalah syirik dan bertentangan dengan kepercayaan tauhid kepada Allah SWT. Khurafat adalah ceritacerita yang mempersonakan, yang dicampuradukkan dengan perkara dusta, sebarang cerita yang benar-benar dusta, sesuatu hal yang tidak masuk akal atau perkara-perkara yang sukar untuk dipercayai kebenarannya, sesuatu perkara mempersonakan berbentuk rekaan atau dongeng (legenda) yang karut atau tahyul yang menyimpang dari ajaran Islam. Manakala istilah tahyul pula adalah semua cerita, sama ada khayalan atau rekaan, ajaranajaran, pantang larang, adat istiadat, ramalan-ramalan, pemujaan atau kepercayaan yang menyimpang dari ajaran Islam. Ia meliputi cerita-cerita yang mempersonakan dan bercampuraduk dengan perkara-perkara yang dusta. Manakala kebudayaan karut ditakrifkan sebagai keseluruhan tatacara hidup serta hasil kegiatan dan penciptaan yang berupa kebendaan atau kerohanian dalam sesuatu masyarakat, tamadun dan peradaban yang direka serta ianya bercanggah dengan ajaran Islam. Ketiga-tiga istilah

51 Hamidah Abdul Wahab, "Petua dan Pantang Larang Tradisional dalam Alam Melayu Sarawak" International Journal of the Malay World and Civilisation (Iman) 1(1), 2013: 89-97. 
ini mempunyai maksud dan kaitan yang rapat di antara satu sama lain. ${ }^{52}$

Ciri-ciri khurafat dan tahyul adalah; (a) cerita-cerita yang tidak didasarkan pada nas-nas syarak sama ada al-Quran atau Sunnah, (b) cerita-cerita yang berunsur mitos dan lagenda, rekaan, dongeng, khayalan atau kepercayaan karut, (c) ceritacerita yang bersumberkan kepada kepercayaan lama dan adat yang bercanggah dengan Islam, (d) cerita-cerita yang berbentuk pemujaan dan permohonan kepada 'makhluk halus' bagi tujuan memudharatkan orang lain dan menyeleweng dari akidah Islam, (e) menggunakan objek-objek tertentu seperti kubur, pokok dan sebagainya bagi tujuan tertentu, (f) cerita-cerita yang mempunyai unsur-unsur negatif dari segi akidah dan syariat Islam. Manakala antara bentuk-bentuk khurafat dan tahyul ialah; (a) kepercayaan kepada nasib sial majal, seperti adat membuang sial, (b) kepercayaan kepada jin dan memohon pertolongan daripadanya, (c) kepercayaan kepada petanda-petanda dan pantang larang, seperti menangguhkan perjalanan jika terdapat biawak melintas kerana dianggap sebagai isyarat benda tidak baik akan berlaku, (d) Memuja objek-objek tertentu, roh nenek moyang dan kubur. ${ }^{53}$

Kehadiran Islam di rantau ini telah membawa perubahan terhadap masyarakat Melayu daripada pelbagai sudut, seperti dalam bidang-bidang bahasa, sastera, adat istiadat dan lainlain sehingga menjadikannya sebahagian daripada dunia Islam. Selain itu, pengaruh Islam merupakan pengaruh terbesar dalam membentuk identiti masyarakat Melayu, walaupun terdapat pengaruh luaran lain seperti Hindu dan Barat. Justeru, setelah Islam bertapak dan berakar umbi di Tanah Melayu, sesetengah kepercayaan dan amalan tradisi yang diwarisi sebelum ini, yakni yang melibatkan animisme dan pengaruh agama Hindu Budha ada yang ditinggalkan, namun ada juga yang masih dikekalkan

52 Rujuk Garis Panduan Bahan Penerbitan Bercetak dan Audio Visual Berhubung dengan Unsur-Unsur Yang Bercanggah dengan Akidah dan Amalan Ahli Sunnah Wal Jamaah.

Ibid. 
dan diamalkan dalam kalangan masyarakat, namun disesuaikan mengikut tuntutan agama Islam. ${ }^{54}$

Masyarakat Melayu merupakan rumpun besar yang mempunyai pelbagai petua yang disaring, diubah suai dan disesuaikan, bergantung kepada suasana dan persekitaran masyarakat tersebut. ${ }^{55}$ Justeru, petua dan pantang larang yang boleh diamalkan mestilah; i) amalan-amalan yang tidak bercanggah dengan al-Quran, Sunnah, Ijmak dan Qiyas, ii) tidak bercanggah dengan akidah bahawa setiap kebaikan atau keburukan, manfaat atau mudarat yang berlaku kepada manusia adalah ketentuan daripada Allah SWT, serta iii) tidak mengubah hukum Allah SWT seperti mengharamkan yang halal ataupun sebaliknya. ${ }^{56}$

Petua dan pantang larang juga merujuk kepada 'urf. Menurut perspektif hukum Islam, sesuatu amalan yang dilakukan secara berulang-ulang dikenali sebagai 'urf. 'Urf dari segi bahasa berasal daripada perkataan 'arafa, ya'rifu, 'irfanan yang bermaksud mengetahui, mengenali dan mengesan. ${ }^{57}$ Dari segi istilah pula, 'urf adalah sesuatu yang biasa diketahui oleh manusia dan mereka mengikutinya sama ada melalui perkataan, perbuatan dan pengakuan. ${ }^{58}$ Ibn Manzur mentakrifkan uruf sebagai sesuatu perbuatan yang dianggap baik iaitu setiap yang diketahui kebaikannya dan diterima amalan tersebut dengan jiwa yang tenang. ${ }^{59}$ Al-Jurjani mendefinisikan uruf sebagai penyaksian akal kepada amalan-amalan yang didasari oleh jiwa dan tabiat-

54 Hamidah Abdul Wahab, "Petua dan Pantang Larang Tradisional dalam Alam Melayu Sarawak," 89-97.

55 Ibid.

56 Mohd. Tamyes Abd. Wahid, Pantang Larang dan Petua Dari Perspektif Islam" (Kertas Kerja dibentangkan di Seminar Pantang Larang Masyarakat di Selangor di PADAT pada 26 November 2014)

57 Ibn Manzūr, Lisan al- 'Arab, 9: 236. Lihat juga, Dewan Bahasa dan Pustaka, Kamus Besar Arab, 1538. Lihat juga,'Abd al-Halim Mansur, al-Mu'jam al-Wasit, c.2 (t.p.:t.t.p., t.t.), 1:595.

58 Qutb, Mu'jam Mustalahat, 284.

59 Muhammad ibn Mukarram ibn `Alī ibn Ahmad ibn Manzūr, al-Lisan al- 'Arabi (al-Rabat: al-Maktab al- Da'im li-Tansiq al-Ta rib fi alwatan al-'Arabī, 1410h). 
tabiat manusia itu diterima dengan baik. ${ }^{60}$ Manakala Abu Zahrah mentakrifkan uruf sebagai kebiasaan yang dilakukan oleh manusia misalnya dalam aspek muamalat dan perkara itu dilakukan secara berterusan. ${ }^{61}$ Abu Zahrah juga menambah bahawa uruf adalah perkara yang dilihat oleh orang Islam mempunyai kebaikan dan tidak mempunyai sebarang kesempitan dan kesulitan dalam mengamalkannya. Ini berdasarkan hadis nabi SAW:

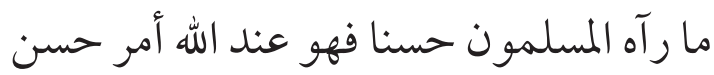

Terjemahan: Apa yang dipandang baik menurut kaum muslimin, maka menurut Allah pun digolongkan sebagai perkara yang baik.

Dapat disimpulkan di sini, bahawa 'urf merupakan sesuatu perkara yang diketahui dan menjadi kebiasaan dalam kalangan manusia sama ada ia melibatkan perkataan, perbuatan dan pengakuan serta diamalkan secara konsisten dan teratur. 'Urf terbahagi kepada enam bahagian iaitu, ${ }^{62}$ ' $u r f$ qawli, ${ }^{63}$ ' $u r f^{\text {' }}$ amali, ${ }^{64}$

60 Syekh Ali bin Sayyid Muhammad Syarif al-Jurjani, al-Ta 'rifat (Bayrūt: Dār al-Kutub al-'Ilmiyah, 2000).

61 Sheikh Muhammad Abu Zahrah, Ușūl al-Fiqh (Qāhirah: Dār al-Fikr al-`Arabī, 2006).

62 Ibid., 284-285. Lihat juga, 'Abd al-Karim Zaydan, al-Wajīz fì Ușūl al-Fiqh (Bayrūt: Muassasah al-Risalah al-Nashirun, 2004), 201.

63 'Urf qawli adalah lafaz yang mudah difahami serta menjadi kebiasaan dalam kalangan orang ramai dan ia menunjukkan makna tertentu.

64 'Urf' amali adalah perbuatan yang menjadi kebiasaan orang ramai dalam bidang muamalah. 
'urf 'am, ${ }^{65}$ 'urf khass, ${ }^{66}$ 'urf șahīh ${ }^{67}$ dan 'urf fasid. ${ }^{68}$ Untuk membolehkan 'urf diambil kira sebagai sumber hukum Islam, para ulama telah mensyaratkan beberapa perkara yang mesti dipenuhi iaitu 'urf mestilah tidak berlawanan dengan nas syarak; 'urf telah diamalkan oleh masyarakat secara menyeluruh dan meluas; 'urf yang akan dirujuk dalam sesuatu tindakan sudah wujud ketika hendak dilakukan tindakan tersebut; dan tidak wujud sesuatu perkataan atau perbuatan yang berterus terang menyalahi 'urf. ${ }^{69}$ Wujud satu kaedah fiqh yang diterima pakai oleh semua ulama adalah (العادة محكمة) yang bermaksud adat dijadikan rujukan bagi menentukan hukum syarak khususnya ketika berlaku perselisihan kerana ia juga merupakan asas pembinaan hukum yang tidak dinaskan.

Di Malaysia, penduduknya terdiri daripada kumpulan etnik Melayu, Cina dan India. ${ }^{70}$ Sebahagian besar penduduk beragama Islam sebanyak 61.3 peratus, Buddha 19.8 peratus, Kristian 9.2 peratus, Hindu 6.3 peratus, Konfusianisme, Toa dan lainlain agama tradisional Cina 1.3 peratus, lain-lain agama 0.4

65 'Urf' $a m$ adalah 'urf yang terkenal dalam sesebuah negara atau 'urf yang diterima oleh orang ramai. 'Urf ini melibatkan satu perbuatan masyarakat yang diamalkan oleh generasi seterusnya.

66 'Urf khass adalah 'urf yang terkenal di sebahagian negeri atau sebahagian manusia sahaja dan ia tidak diamalkan di tempat lain.

67 'Urf sahih adalah sesuatu yang diketahui oleh manusia dan terbiasa dalam kalangan mereka, tidak menyalahi dalil syarak, tidak menghalalkan yang haram dan tidak membatalkan yang wajib.

68 'Urf fasid adalah sesuatu yang diketahui oleh manusia dan menjadi kebiasaan di antara sebahagian mereka, tetapi ia menyalahi hukum syarak mengharamkan yang halal dan membatalkan yang wajib. Urf fasid tidak diambil kira oleh syarak kerana ia ditolak oleh Syariah Islam.

69 'Abd al-Karim, al-Wajīz fì Ușūl al-Fiqh, 203.

70 Kira-kira 67.4 peratus penduduk terdiri daripada orang Melayu, 24.6 peratus Cina, dan 7.3 peratus India. Selebihnya, 0.7 peratus terdiri daripada kumpulan etnik seperti Iban, Dayak, Kadazan, Bajau, Bidayuh, Murut yang tinggal di Sabah dan Sarawak. 
peratus, tiada agama 0.7 peratus dan tidak diketahui 1 peratus. $^{71}$ Berdasarkan kepada peratusan agama mengikut kumpulan etnik ini, menunjukkan Malaysia mempunyai masyarakat yang berbilang kaum di mana masyarakatnya terdiri daripada beberapa kumpulan etnik atau suku bangsa yang berbeza-beza. Malah setiap kumpulan etnik atau suku bangsa bebas mengamalkan adat resam, upacara keagamaan, kebudayaan dan kesenian yang diwarisi daripada generasi terdahulu. Hal ini menjelaskan bahawa Malaysia mempunyai latar belakang 'urf setempat yang berbezabeza mengikut kumpulan etnik masing-masing. Justeru, Islam sebagai sebuah agama yang universal memperakukan mana-mana 'urf setempat yang selaras dengan syarak termasuk dalam kategori 'urf șahih. Manakala Islam menolak mana-mana 'urf setempat yang jelas bertentangan dengan syarak dan ia termasuk dalam kategori 'urffasid. Walau bagaimanapun, terdapat juga sesetengah ' urf setempat yang bercanggah dengan syarak kemudiannya diolah atau dipinda supaya selaras dengan syariat Islam.

\section{PENUTUP}

Petua dan pantang larang dalam kalangan masyarakat Melayu merupakan pengaruh daripada pelbagai elemen termasuk animisme, Buddha, Hindu, Islam dan Barat. Tidak dinafikan bahawa masyarakat Melayu mengamalkan pelbagai petua dan pantang larang turun temurun daripada generasi terdahulu tanpa diperhalusi dengan betul. Hal ini mewujudkan permasalahan dan kekeliruan dalam kalangan masyarakat sekiranya petua dan pantang larang tersebut bertentangan dengan agama Islam. Islam tidak menghalang sebarang amalan petua dan pantang larang yang memberikan kebaikan serta penerapan nilai agama kepada wanita hamil dan pasangan. Bahkan hal ini wajar diteruskan kepada generasi yang seterusnya. Namun begitu, bagi petua dan pantang larang yang bercanggah dengan ajaran Islam perlu diasimilasikan

71 Department of Statistics Malaysia, "Population Distribution and Basic Demographic Characteristic Report 2010 (Updated: 05/08/2011)," laman sesawang Department of Statistics Malaysia, official Portal, dicapai 10 Jun 2019,https://www.statistics.gov.my/ index.php? $\mathrm{r}=$ column/cthemeByCat\&cat=117\&bul_id=MDMxdHZ jWTk1SjFzTzNkRXYzcVZjdz09\&menu_id=L0pheU43NWJwRW VSZklWdzQ4TlhUUT09. 
dengan neraca nilai-nilai Islam yang betul. Justeru, jabatan agama wajar meneliti petua dan pantang larang yang diamalkan oleh masyarakat tempatan agar tidak bertentangan dengan hukum Islam. Langkah ini perlu agar masyarakat tidak terkeliru dan terus mengamalkan adat yang bercanggah dengan agama bahkan memberikan satu pencerahan mengenai petua dan pantang larang yang boleh dipegang atau diamalkan. Hal ini kerana aktiviti yang berkaitan dengan petua dan pantang larang melambangkan cara hidup sesebuah masyarakat.

\section{RUJUKAN}

Ahmad Moghni Salbani, S. O. Amalan Kearifan Tempatan dalam Masyarakat Melayu/Nusantara. Pulau Pinang: Universiti Sains Malaysia, 2012.

Ahmad, A. S. Warisan Perubatan Melayu. Selangor: Dawama Sdn. Bhd., 2005.

Al-Hanafî, a.-S. A.-H.-H.-J. al-Ta rifat. Bayrūt: Dār al-Kutub al'Ilmiyah, 2000.

Ali, J. M. al-Lisan al- 'Arabi. al-Rabat: al-Maktab al-Da'im liTansiq al-Ta 'rib fi al-watan al-'Arabī, 1410H.

Ani Haji Omar, "Pantang Larang dalam Kalangan Orang Melayu: Analisis Dari Perspektif Teori Spb4k", Melayu: Jurnal Antarabangsa Dunia Melayu 7, no. 1 (2014), 82.

Baharuddin, A. Perubatan dan Kesihatan di Kalangan Orang Melayu. Kuala Lumpur: Akademi Pengajian Melayu, 1993.

Barakbah, A. Ensiklopedia Perbidanan Melayu. Kuala Lumpur: MPH Group Printing (M) Sdn Bhd., 2017.

Bidan, M. Rawatan Tradisional Ketika Mengandung, Selepas Bersalin \& Tips Penjagaan Bayi. Kuala Lumpur: Usnie Sdn. Bhd., 2001.

Faisal@Ahmad Faisal Abdul Hamid, N. W. Perubatan Melayu Tradisional: Kitab Tibb Pontianak. Jurnal Al-Tamaddun, 2012.

Hashim, S. Pengurusan Hukum Syarak Menurut Perspektif Usul Fiqh: Sumber Hukum Syarak. Johor Bahru: UTM Press, 2016. 
Kadir, W. A. Beberapa Aspek Masyarakat dan Budaya Melayu. Kota Bharu dan Petaling Jaya: Masfami Enterprise, 1993.

Kadir, W. A. Struktur dan Organisasi Masyarakat dan Budaya Melayu. Kota Bharu dan Petaling Jaya: Masfami Enterprise, 1993.

Kadir, W. A. Tradisi dan Perubahan Masyarakat dan Budaya Melayu. Kuala Lumpur: Pustaka Ilmu, 2002.

Machita Othman. Adat Melenggang Perut di Kalangan Masyarakat Melayu. Jurnal Warisan Indera Kayangan 5 (1993).

Mohd Anuar Ramli dan Syamsul Azizul Marinsah, "Kepercayaan Kenan dalam Masyarakat Melayu: Kajian dari Perspektif Hukum Islam.” Jurnal Manusia dan Masyarakat 25 (2014), 34.

Mohd Khairulnazrin Mohd Nasir, M. S. Kepercayaan Animisme Menurut Perspektif Sunnah Nabawi dan Ahli Antropologi Barat: Satu Kajian Awal. Jurnal Pengajian Islam, 2016.

Mohd Nizho Abdul Rahman, A. M. Antara Fatwa dan Petua dalam Masyarakat Melayu: Satu Kajian Penilaian. Persidangan Antarabangsa Sains Sosial dan Kemanusiaan 2018. Selangor: Kolej Universiti Islam Antarabangsa Selangor, 2018.

Riji, H. b. Penjagaan Kesihatan dan Rawatan: Prinsip dan Teori dalam Perubatan Melayu. Tesis Kedoktoran: Universiti Malaya, 1999.

Tabataba'i, A. S. al-Mizan fi Tafsir al-Qur'an. Bayrūt: alMu'assasat al-A`lami, 1970.

Wahab, H. A. Petua dan Pantang Larang Tradisional dalam Alam Melayu Sarawak. International Journal of the Malay World and Civilisation. 2013.

Yusmilayati Yunos, M. Y. Kepandaian Orang Melayu dalam mentafsir ruang perubatan tradisional. Malaysia Journal of Society and Space, 12, no. 11 (2016), 79-91.

Zahrah, M. A. Ușūl al-Fiqh. Qāhirah: Dār al-Fikr al-`Arab̄̄, 2006. 
Jurnal Fiqh, Vol. 16 No. 1 (2019) 191-224 